\title{
Study of the flora richness of the region of Guelma (North East of Algeria): production of a preliminary list of species found
}

\author{
Nouasria Djaouida ${ }^{1,2}$, Mezadjeri Lyamine',Tahar Ali² \& Hadef Azzedine' \\ ${ }^{1}$ Department of Natural and Life Sciences, Faculty of Sciences, University August 20, 1955 Skikda BP 26 Road d'El \\ Hadaiek Skikda 21000,Algeria; email: djaouida24@yahoo.fr / 1.mezedjri@univ-skikda.dz \\ ${ }^{2}$ Department of Biology, Faculty of Sciences, Badji Mokhtar University Annaba 23000, Algeria
}

\begin{abstract}
The present study is based on the inventory of the flora of a station characterized by an abundant population of Pistacia lentiscus L. and consists of a quantitative and qualitative analysis of this flora through significant parameters: global composition (number of taxa), morphological types, biological types, diaspore types and biogeographic distribution, in order to underline the importance of the floristic diversity of this region. The inventory carried out made it possible to identify 102 species belonging to 92 genera and 43 families, of which the most represented are those of Asteraceae $23.52 \%$. The established biological spectrum shows a predominance of therophytes over the other forms with $32.35 \%$ where the Mediterranean element dominates $(64.35 \%)$, this flora is characterized morphologically by the dominance of annual herbaceous plants (33.33\%) and biologically by Therophytes as well as Anemochore species (29.41\%).
\end{abstract}

KEY WORDS Algeria; floristic biodiversity; Inventory; Pistacia lentiscus.

Received 20.12.2020; accepted 30.08.2021; published online 04.11.2021

\section{INTRODUCTION}

Mediterranean plant biodiversity is the product of a complex and eventful palaeogeography, but also of a traditional and harmonious use of the environment by man (Iboukassene, 2008).

In a global context of biodiversity conservation, the study of the flora of the Mediterranean basin is of great interest, given its great richness linked to the heterogeneity of historical, paleogeographic, paleoclimatic, ecological and geological factors which characterize it, as well as "to the secular impact of human pressure" (Quezel et al., 1980).

Most Mediterranean forests represent unbalanced ecological systems, generally well adapted in space and time to various constraints and therefore to changes in the dynamics or structure and architecture of the populations that they can generate (Barbero \& Quézel, 1989).
In an ecosystem, plants are the first link in the trophic (food) chain and the support for all animal life. Without plants, animals could not live since they are unable to manufacture all or part of their constituents (Babali, 2010).

According to Loisel (1978), vegetation is the result of the integration of floristic, climatic, geological, historical, geomorphological and edaphic factors.

It is in this context that it seemed necessary to us to carry out this work, that it is based on the inventory of the flora of the zone of Roknia and consists of a quantitative and qualitative analysis of this flora through significant parameters (global composition, morphological types, biological types, diaspore type and biogeographic distribution) in order to underline the importance of the floristic diversity of this zone and to analyze the main factors which influence the vegetation cover. 


\section{MATERIAL AND METHODS}

\section{Study area}

The Wilaya of Guelma is located in the NorthEast of the country and constitutes, from a geographical point of view, a meeting point, even a crossroads, between the industrial poles of the North (Annaba and Skikda) and the centers of exchanges in the South (Oum El Bouaghi and Tébessa). It occupies a middle position between the North of the country, the Highlands and the South.

The wilaya of Guelma covers an area of $3,686.84 \mathrm{~km}^{2}$ and is bounded by (Fig. 1):

- the Wilaya of Annaba in the North;

- the Wilaya of El Taref in the North East;

- the Wilaya of Souk Ahras in the East;

- the Wilaya of Oum El-Bouaghi in the South;

- the Wilaya of Constantine in the West;

- the Wilaya of Skikda in the Northwest.

The territory of the Wilaya is characterized by a subhumid climate in the center and the North and semi arid towards the South. This climate is mild and rainy in winter and hot in summer. The temperature, which varies from $4{ }^{\circ} \mathrm{C}$ in winter to 35.4 ${ }^{\circ} \mathrm{C}$ in summer, is on average $17.3{ }^{\circ} \mathrm{C}$.

The geography of the Wilaya is characterized by a diversified relief of which we essentially retain an important forest cover and the passage of Seybouse which constitutes the main watercourse, it is agro-silvopastoral vocation with: $(27 \%)$;

- the presence of a relatively large forest cover

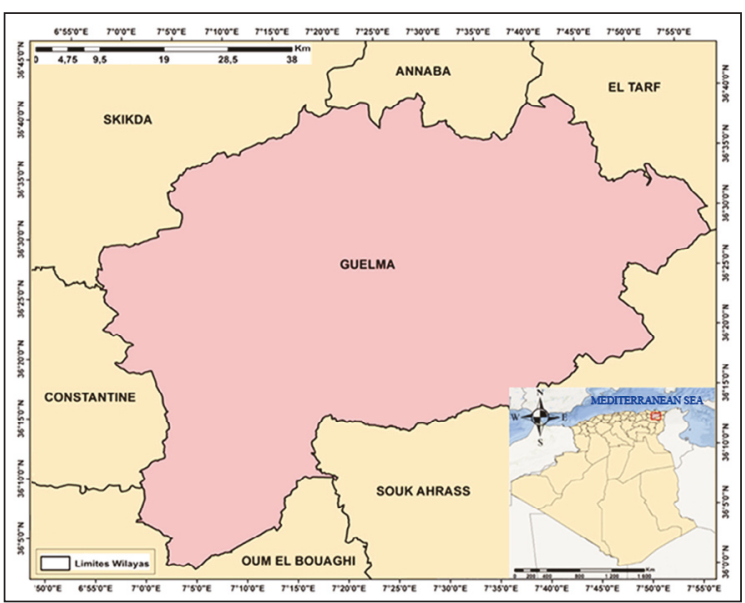

Figure 1. Geographical location of the study area.
- the use of agriculture of (35\%) of the total area; - the dominance of scrub and scrub.

\section{Sampling}

Between 2016 and 2017, dozens of visits between prospecting and carrying out floristic surveys were carried out in the study area.

The sampling of plant communities must therefore include two phases: the first consists of the analysis of the samples themselves, to check whether they meet the criteria of homogeneity and sufficient representativeness, the second corresponds to the comparison of the samples in order to draw valid conclusions for the entire community, or to compare communities (Gounot, 1969).

In our case, the study of the vegetation was carried out using the minimum area method which consists in choosing locations as typical as possible while noting the environmental conditions. A reading is taken every $10 \mathrm{~cm}$ along a $20 \mathrm{~m}$ line (Gounot, 1969).

We carried out a total of 60 floristic surveys.

The determination of the taxa was carried out following Quezel \& Santa $(1962,1963)$ and Ozenda (1977), with consultation of other works of Bayer et al. (1990), Bartels (1998) and Boucher (2000).

\section{RESULTS}

The flora of the Roknia area encompasses several species of spontaneous plants. The 102 listed species belong to 92 genera and 43 botanical families (Table 1).

The most represented families are in order of importance: the Asteraceae (24 species: $23.52 \%$ ), the Lamiaceae (6 species: $5.88 \%$ ), the Apiaceae (5 species: $4.90 \%$ ), the Fabaceae (5 species: $4.95 \%$ ), the Poaceae (4 species: $3.96 \%$ ), the Euphorbiaceae (4 species: $3.92 \%$ ), the Liliaceae (4 species: $3.92 \%$ ), the Rosaceae (4 species: $3.92 \%$ ). These 8 families alone represent 56 species $(54.90 \%)$ of the region's flora richness.

The species recorded belong to different morphological types (Table 2 and Fig. 2).

The dominance of annual herbaceous plants (34 species: $33.33 \%$ ) over herbaceous perennial plants (32 species: $31.37 \%$ ), herbaceous biennial plants (11 species: 10.78\%), and bushes (9 species: $8.82 \%$ ), woody perennial (7 species: $6.86 \%$ ) fol- 


\begin{tabular}{|c|c|c|c|c|c|}
\hline Family & genera & species & Family & genera & species \\
\hline Asteraceae & 21 & 24 & Cactaceae & 1 & 1 \\
\hline Lamiaceae & 5 & 6 & Caprifoliaceae & 1 & 1 \\
\hline Apiaceae & 5 & 5 & Caryophyllaceae & 1 & 1 \\
\hline Fabaceae & 5 & 5 & Chenopodiaceae & 1 & 1 \\
\hline Poaceae & 4 & 4 & Convolvulaceae & 1 & 1 \\
\hline Euphorbiaceae & 3 & 4 & Cistaceae & 1 & 1 \\
\hline Liliaceae & 4 & 4 & Cucurbitaceae & 1 & 1 \\
\hline Rosaceae & 3 & 4 & Glubulariaceae & 1 & 1 \\
\hline Boraginaceae & 3 & 3 & Iridaceae & 1 & 1 \\
\hline Geraniaceae & 2 & 3 & Juncaceae & 1 & 1 \\
\hline Malvaceae & 2 & 2 & Myrtaceae & 1 & 1 \\
\hline Oleaceae & 2 & 3 & Papaveraceae & 1 & 1 \\
\hline Arecaceae & 2 & 2 & Ranonculaceae & 1 & 1 \\
\hline Ericaceae & 2 & 2 & Resedaceae & 1 & 1 \\
\hline Plantaginaceae & 1 & 2 & Rhamnaceae & 1 & 1 \\
\hline Primulaceae & 1 & 2 & Rubiaceae & 1 & 1 \\
\hline Urticaceae & 1 & 2 & Smilacaceae & 1 & 1 \\
\hline Anacardiaceae & 1 & 1 & Scrophulariaceae & 1 & 1 \\
\hline Apocynaceae & 1 & 1 & Tamaricaceae & 1 & 1 \\
\hline Araceae & 1 & 1 & Thymelaeaceae & 1 & 1 \\
\hline Asparagacea & 1 & 1 & Verbenaceae & 1 & 1 \\
\hline Brassicaceae & 1 & 1 & & & \\
\hline
\end{tabular}

Table 1. List of families with the number of genera and species.

lowed by shrubs (6 species, or 5.88\%). The least represented morphological types are trees (1 species: $0.98 \%$ ), undershrubs ( 1 species: $0.98 \%$ ) and arborescent (1 species: $0.98 \%$ ).

Table 3 and Fig. 3 show the distribution of biological types taking into account the presence of species (the number of species).

This Table 3 shows that within the region of Roknia, the most dominant biological type is that of Therophytes which are represented with 33 species $(32.35 \%)$ followed by Hémicryptophytes and Phanerophytes which are represented respectively by 30 species $(29.41 \%)$ and 21 species (20.58\%).

The Chamephytes and Geophytes each contain 9 species $(08.82 \%)$.

The gross global spectrum of dissemination types (Table 4, Fig. 4) shows the preponderance of species whose seeds are dispersed by wind, the Anemochores with 30 species (29.41\%). 


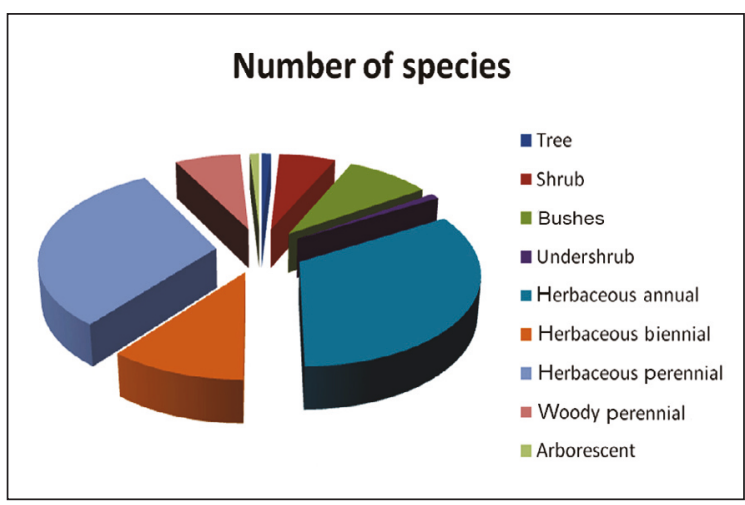

Figure 2. Distribution of morphological types at the level of the study area.

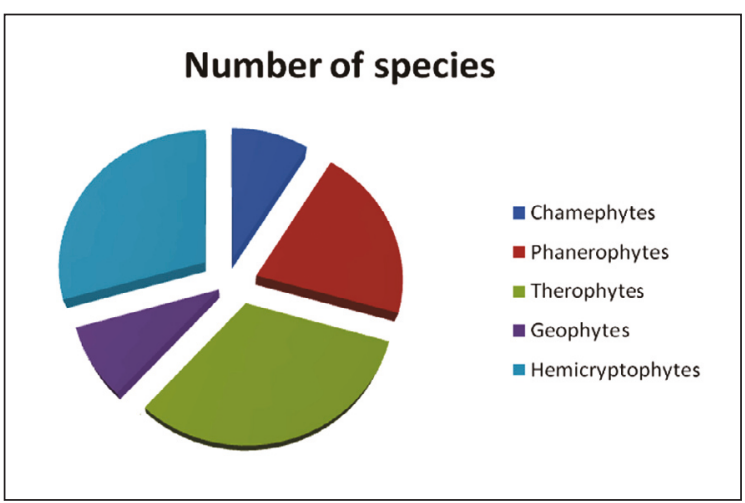

Figure 3. Distribution of biological types in the study area.

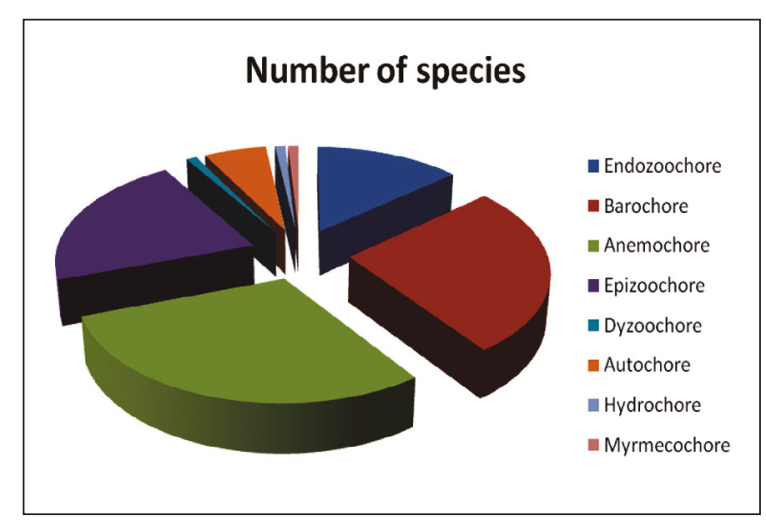

Figure 4. Distribution of diaspora types in the study area.

The species whose seeds are dispersed by gravity, in the immediate vicinity of the mother plant: the Barochores occupy the second place with 27 species $(26.47 \%)$, followed by Epizoochores qualifying the dispersion of seeds by transport on the plumage or coat of animals with 22 species

\begin{tabular}{|l|c|c|}
\hline Morphological type & $\begin{array}{c}\text { Number } \\
\text { of species }\end{array}$ & Rate (\%) \\
\hline Tree & 1 & 0.98 \\
\hline Shrub & 6 & 5.88 \\
\hline Bushes & 9 & 8.82 \\
\hline Undershrub & 1 & 0.98 \\
\hline Herbaceous annual & 34 & 33.33 \\
\hline Herbaceous biennial & 11 & 10.78 \\
\hline Herbaceous perennial & 32 & 31.37 \\
\hline Woody perennial & 7 & 6.86 \\
\hline Arborescent & 1 & 0.98 \\
\hline
\end{tabular}

Table 2. Global analysis of morphological types at the level of the study area.

\begin{tabular}{|l|c|c|}
\hline Biological type & $\begin{array}{c}\text { Number } \\
\text { of species }\end{array}$ & Rate (\%) \\
\hline Chamephytes & 9 & 8.82 \\
\hline Phanerophytes & 21 & 20.58 \\
\hline Therophytes & 33 & 32.35 \\
\hline Geophytes & 9 & 8.82 \\
\hline Hemicryptophytes & 30 & 29.41 \\
\hline
\end{tabular}

Table 3. Global analysis of biological types at the level of the study area.

\begin{tabular}{|l|c|c|}
\hline Type diaspore & $\begin{array}{c}\text { Number } \\
\text { of species }\end{array}$ & Rate (\%) \\
\hline Endozoochore & 14 & 13.72 \\
\hline Barochore & 27 & 26.47 \\
\hline Anemochore & 30 & 29.41 \\
\hline Epizoochore & 22 & 21.56 \\
\hline Dyzoochore & 1 & 0.98 \\
\hline Autochore & 6 & 5.88 \\
\hline Hydrochore & 1 & 0.98 \\
\hline Myrmecochore & 1 & 0.98 \\
\hline
\end{tabular}

Table 4. Global analysis of diaspora types in the study area.

(21.56\%) and the Endozoochores whose seeds are dispersed after intestinal transit in animals with 14 species $(13.72 \%)$.

The last places are respectively occupied by the Autochores which disperse seeds by a mechanical action of the plant itself with 6 species $(5.88 \%)$, 
the Hydrochores whose seeds are dispersed by water with 1 species (0.98\%), Myrmecochores which disperse seeds by ants with 1 species $(0.98 \%)$ and dyzoochoria whose seeds are dispersed by an animal then stored and sometimes forgotten by an animal with 1 species $(0.98 \%)$.

The species composing the vegetation of the Roknia region are distributed phytogeographically as shown in Table 5.

From Fig. 5, we see that the Mediterranean species predominate in this formation with 65 species $(63.72 \%)$. Cosmopolitan species come in

\begin{tabular}{|l|c|c|}
\hline \multicolumn{1}{|c|}{ Phytogeographic distribution } & $\begin{array}{c}\text { Number of } \\
\text { species }\end{array}$ & Rate (\%) \\
\hline Mediterranean & 65 & 63.72 \\
\hline Cosmopolitan & 11 & 10.78 \\
\hline EuroAsian & 5 & 4.90 \\
\hline Circumboreal & 1 & 0.98 \\
\hline Subtropical & 1 & 0.98 \\
\hline Euro central, W-Asia, Africa & 9 & 8.82 \\
\hline Atlantic & 5 & 4.90 \\
\hline Paleotemperate & 2 & 1.96 \\
\hline Holarctic & 1 & 0.98 \\
\hline Med, S-Euro, W-Asia & 1 & 0.98 \\
\hline Tropical America & 1 & 0.98 \\
\hline
\end{tabular}

Table 5. Distribution of types of phytogeographic distribution at the level of the study area. second position with 11 species $(10.78 \%)$ followed by species from Central Europe, Western Asia and Africa with 9 species $(8.82 \%)$ then the species that characterize the regions: Eurasians and Atlantic with each 5 species $(4.90 \%)$ followed by Paleotemperate species with 2 species (1.96\%). The species, Circumboreal, Holartic, Tropical America, Mediterranean, Euro-South, Asia-West, and Subtropical are the least represented with a rate of $0.98 \%$.

\section{DISCUSSION}

Compared to the 131 botanical families of all the flora of Algeria identified by Quezel \& Santa (1962-1963), the study region contains $32.82 \%$ of these families.

The preponderant place occupied by the Asteraceae and the Lamiaceae is justified, since they are cosmopolitan families widespread over the entire surface of the globe (Ozenda, 1977).

The ratio of the number of families to the number of species is high $(42.15 \%)$, it is $34 \%$ for the region of Ziban (Salemkour et al., 2012), 10\% for the south of Oran (Bouzenoune, 1984) and 18\% for South Algiers (Melzi, 1986). This difference is explained by the fact that in the studied area, most families are represented by only one or two genera, and most genera by only one or two species (Hetz, 1970), for example the families of Malvaceae, Plantaginaceae, Caprifoliaceae, Cistaceae, Globulari-

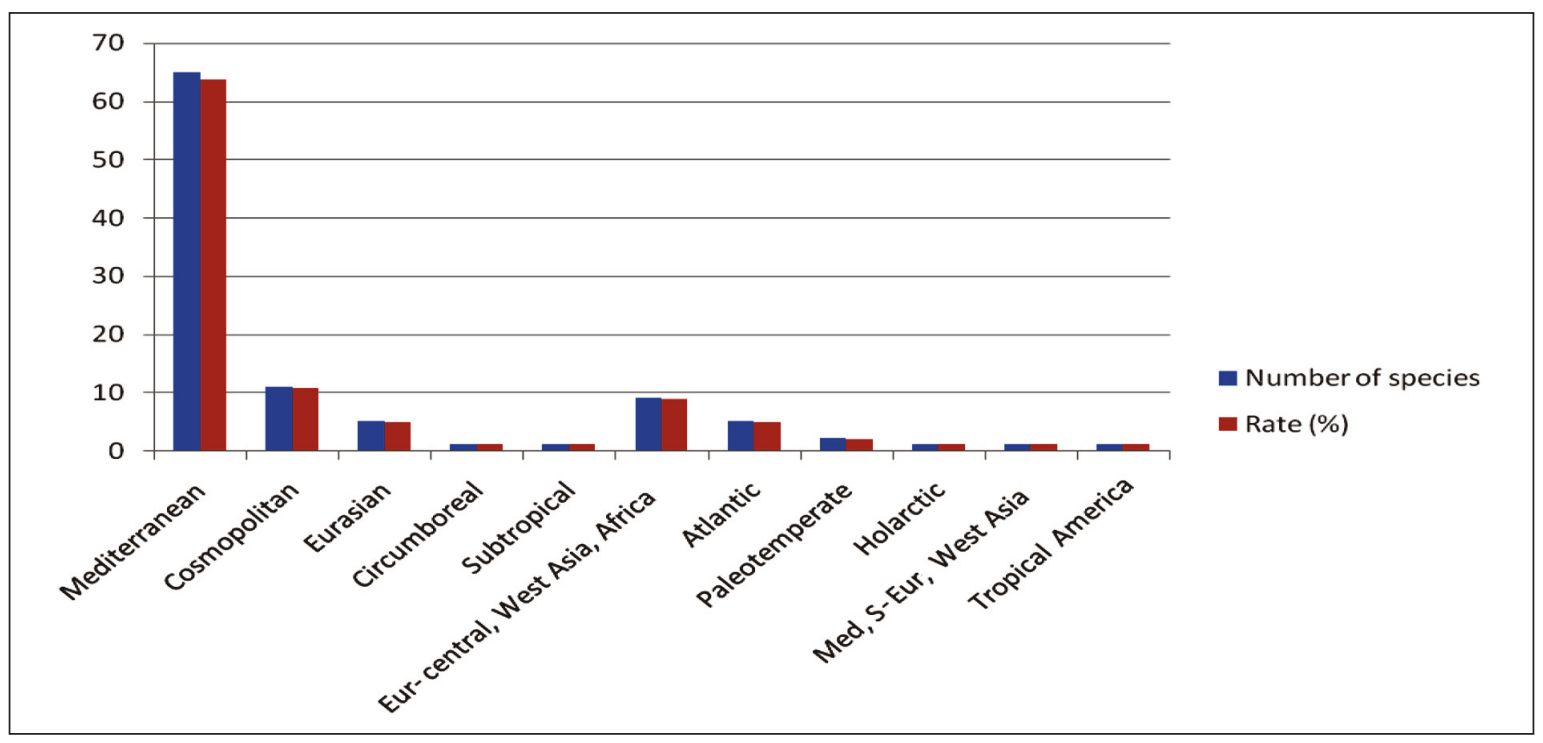

Figure 5. Distribution of the types of phytogeographic distribution in the study area. 
aceae, Tamaricaceae, etc. and of the genera $E u$ phorbia, Urtica, Tamarix, Olea, Globularia, etc., in our study (Table 1).

The generic coefficient, namely the ratio of the number of genera to the number of species, is equal to $90.19 \%$. This high value of this coefficient is indicative of depleted flora (Ozenda, 1977).

Romane (1987) shows that there is a good correlation between biological types and many morphological characters.

The biological type of a plant is the result, on the vegetative part of its body, of all biological processes including those which are modified by the environment during the life of the plant and which are not hereditary (Polumin, 1967).

Drought, fires, grazing and land clearing all these generate a regressive evolution of the vegetation cover of the study area. This regression results in the invasion of annual herbaceous plants with a short life cycle; they express a strategy of adaptation to unfavorable conditions and a form of resistance to severe climatic conditions. On the other hand, perennial woody plants are more demanding in terms of water and trophic needs.

We observe that the therophytes present the highest rate for, which indicates a very strong anthropic action. Grazing enriches the soil with nitrates and allows the development of ruderae, especially annuals. In addition to anthropization, therophytization is thought to have its origin in the phenomenon of aridification (Barbero et al., 1990).

The spectra of diaspores in a group are a representation of types of diaspores. They provide information on the nature of the species' diaspores and give indications of their mode of dissemination, which reflects the physiognomy of the group or of the community considered (Ngok, 2005 in Kaboyi, 2004).

The types of diaspores retained correspond to the categories defined by Danserau \& Lems (1957). These are essentially based on morphological criteria and they make it possible to tend towards a certain objectivity when the flora studied is not well known (Evrard, 1968 in Kaboyi, 2004).

For the biogeographic element, several works have been carried out in this area. We can cite those of Axelrod (1973), Axelrod \& Raven (1978) and Quezel, (1978, 1985, 1995). Quezel (1983) explains the biogeographical diversity of Africa by the climatic modifications which have been severely suffered in this region since the Miocene, which leads to the migration of tropical flora (Aboura, 2006).

The lack of research and publications on plant biodiversity in the study area prevented us from making comparisons of results at the national level.

\section{CONCLUSIONS}

The Roknia area, like the whole Mediterranean region, is characterized by a very important biodiversity in terms of flora. We have identified 102 species, the large part of which consists in particular of therophytes, which represent $32 \%$ of all existing vegetation. Biological and phytogeographic diversity is conditioned by climatic factors which play an essential role for a very large part of the vegetation, to promote the process of biological recovery. Thus anthropogenic factors are factors of instability of plant formations where they lead to an extension of therophytic formations to annual lawns with a proliferation of toxic or thorny species.

This work remains insufficient in our humble opinion. To be more complete, it would need:

- to carry out an in-depth study of the type of soil to better understand the existing interactions between plant species and environmental parameters and consequently to interpret their installations;

- a faunistic study, necessary to highlight the ecological importance of this site as well as the role of its preservation;

We must protect this maquis against all threats that degrade it.

\section{REFERENCES}

Aboura R., 2006. Comparison phytoecological of atriplexaies located north and south of Tlemcen. Master's thesis in Biology. Option: plant ecology. Abou Baker Belkaid-Tlemcen University.

Axelrod D.I., 1973. History of Mediterranean ecosystem in California. In: Dicastri Et Money H.A. 5 (Eds.), Mediterranean type ecosystems origin and structure - ecological, studies, New York, Springier, $\mathrm{n}^{\circ}$ 7: pp. 225-283.

Axelrod D.I \& Raven P., 1978. Late cretacous and tertiary history of Africa.

Bayer E., Buttler K.P., Finkenzeller X. \& Grau J., 1990. Guide de la Flore Méditerranéenne. Caractéristiques, habitat, distribution et particularités de 536 
espèces. Editions Delachaux et Niestlé, Neuchâtel, Paris, $177 \mathrm{pp}$.

Bartels A., 1998. Guide to plants in the Mediterranean basin . Edition Eugen Ulmer 400 pp.

Babali B., 2010. Inventory of the vegetation cover of the Tlemcen region. Master in Ecology and Environment. University of Tlemcen.

Barbero M. \& Quézel P., 1989. Structures, sclerophyllous forest architectures and fire prevention. Bulletin Ecology, 20: 37-56.

Boucher, 2000. The flora of the Mediterranean mountains, supplemented by 10 botanical routes.

Bouzenoune A., 1984. Phytoecological and phytosociological study of plant groups in South Oran. Third cycle thesis, University of Science and Technology, Houari Boumediene, Algiers.

Danserau P. \& Lems K., 1957. The grading of dispersal types in plant communities and their Ecological significance. Contributions de Institut Botanique de l'Université de Montréal, 71: 1-52.

Gounot M., 1969. Methods for the quantitative study of vegetation. Masson, Paris, $314 \mathrm{pp}$.

Hetz A., 1970. The vegetation of the earth. Edition Masson et Cie, Paris, 133 pp.

Iboukassene S., 2008. Vegetation dynamics of anthropized Quercus suber forests in North East Algeria (El-Kala National Park). Doctoral thesis. Catholic University of Louvain. Faculty of Biological, Agronomic and Environmental Engineering, Department of Environmental Sciences and Regional Planning. Water and Forests Unit.

Kaboyi C., 2004. Floristic study of natural vegetation in an anthropized environment: case of xerophilic shrub formation in Cibinda, north of Bukavu. Bachelor of Science Thesis Option: Biology. University of Kisangani - University center extension of $\mathrm{Bu}-$ kavu.

Loisel R., 1978. Phytosociology and phytogeography; phytogeographic significance of the French continen- tal South - East Mediterranean. Documents Phytosociologiques, N.S., 2: 302-314.

Melzi S., 1986. Phytoecological approach to the desertification process in a pre-Saharan sector: MessaadDjelfa. Magister thesis. University of Science and Technology, Houari Boumediene, Algiers, 133 pp.

Ozenda P., 1977. Flore du Sahara, 2nd edition. CNRS, Paris, $622 \mathrm{pp}$.

Polumin N., 1967. Elements of botanical geography. Ed. Gauthiers Willars, Paris: pp. 30-35.

Quezel P. \& Santa S., 1962-1963. New flora from Algeria and the southern desert regions. C.N.R.S. Paris. 2 vol. $1170 \mathrm{pp}$.

Quezel P., 1985. Definition of the Mediterranean region and the origin of its flora. Gomez-Campo Edit - "Plant conservation in the Mediterranean area" Junk, Dordrecht, pp. 9-24.

Quezel P., 1978. Analysis of the flora of Mediterranean and Saharan Africa Annals of the Missouri Botanical Garden, 65: 479-534.

Quezel P., Ganisans J. \& Gruber M., 1980. Biogéographie et mise en place des flores méditerranéennes. Naturalia Monspeliensia, ${ }^{\circ}$ Hors série, pp 41-51.

Quezel P., 1983. Flora and vegetation of North Africa, their significance according to the origin, evolution and migrations of flora and past vegetation structures. Bothalia, 14: 411-416

Quezel P., 1995. La flore du bassin méditerranéen: origine, mise en place, endémisme. Ecologia Mediterranea, 20: 19-39.

Romane F., 1987. Efficiency of the distribution of plant growth forms for the analysis of vegetation on a regional scale. Case of a few thickets of the Languedoc holm oak. Doctoral Thesis Sciences Universite from Aix-Marseille III, 153 pp.

Salemkour N., Chalabi K., Farhi Y. \& Belhamra M., 2012. Floristic inventory of the Ziban region. Journal Algérien des Régions Arides, 9-11: 3-16. 
. 
